\title{
PENERAPAN PENDEKATAN KONTEKSTUAL UNTUK MENINGKATKAN SIKAP ILMIAH SISWA PADA PEMBELAJARAN GAYA DI KELAS V SEKOLAH DASAR
}

\author{
Iin Hindasah*)
}

\begin{abstract}
Abstrak
Penelitian ini dilaksanakan berdasarkan permasalahan yang ditemui di ruang kelas. Pada saat belajar, motivasi belajar siswa terhadap materi IPA kurang sehingga pemahaman siswa rendah. Oleh karena itu dilaksanakan penelitian tindakan kelas (PTK) kelas V SDN Sindanglaya 4 sebagai upaya untuk meningkatkan sikap ilmiah dan pemahaman siswa pada pembelajaran IPA pokok bahasan gaya dengan menggunakan pendekatan kontekstual yang dilaksanakan melalui diskusi dan menempuh tujuh langkah kontekstual. Penelitian ini dilakukan dengan tujuan untuk meningkatkan sikap ilmiah dan pemahaman siswa dalam pelajaran IPA di sekolah dasar.

Teknik pengumpulan data yang digunakan adalah pedoman observasi, catatan lapangan, lembar wawancara, lembar evaluasi dan kamera. Data yang diperoleh dianalisis dan direfleksi dengan menggunakan metode deskriptif. Hasil penelitian menunjukkan Dari hasil penelitian, diperoleh kesimpulan bahwa sikap ilmiah dan pemahaman siswa pada pembelajaran IPA pokok bahasan gaya di kelas V Sekolah Dasar dapat ditingkatkan melalui penerapan pendekatan kontekstual. Dengan demikian direkomendasikan kepada peneliti selanjutnya dalam melaksanakan pembelajaran kontekstual, hendaknya pembelajaran lebih menekankan pada proses sehingga dapat mengembangkan sikap ilmiah siswa.
\end{abstract}

Kata Kunci: Pendekatan Kontekstual, Sikap Ilmiah, Gaya, Pembelajaran Gaya

\section{A. Pendahuluan}

Pembelajaran IPA, terutama di Sekolah Dasar (SD) seyogyanya lebih menekankan pada keterampilan proses. Dalam proses belajar mengajar IPA haruslah mengandung tiga dimensi, yaitu IPA sebagai proses, IPA sebagai suatu produk, dan IPA sebagai faktor yang mengubah sikap dan pandangan peserta didik terhadap alam semesta dari sudut pandang mitologis menjadi sudut pandang ilmiah. Hal tersebut sesuai dengan pernyataan Jhon Dewey (Karli dan Yuliartiningsih, 2002:7) yaitu bahwa pengalaman belajar seseorang diperoleh melalui bekerja/melakukan sehingga hasilnya tidak mudah dilupakan, dan menjadi pembelajaran yang bermakna serta tersimpan pada memori dalam jangka yang lama.

Kenyataan di lapangan, motivasi belajar siswa terhadap materi IPA terlihat rendah. Siswa terlihat bosan karena pembelajaran IPA terkesan sebagai cerita mitos dan tidak realistis. Saat ini, pembelajaran IPA yang dilakukan masih didominasi oleh kelas yang berfokus pada guru sebagai utama pengetahuan, 
sehingga ceramah akan menjadi pilihan utama dalam menentukan strategi belajar, sehingga sering mengabaikan pengetahuan awal siswa. Hal tersebut bertolak belakang dengan pendapat Ausubel (Dahar, RW., 1996:103) yang mengemukakan bahwa faktor paling penting yang mempengaruhi belajar siswa adalah apa yang telah diketahui siswa (pengetahuan awal). Dengan demikian pembelajaran yang dilakukan guru harusnya mampu mengaitkan antara pengetahuan yang akan diperoleh siswa dengan konsep-konsep yang sudah ada dalam struktur kognitif siswa.

Untuk itu diperlukan suatu pendekatan belajar yang memberdayakan siswa. Salah satu pendekatan yang memberdayakan siswa dalah pendekatan kontekstual. Menurut US Departement of Education (Doantara yasa, http://ipotes.wordpress. com/2008/05/13/ pendekatan-kontekstual-atau-contextual-teaching-and-learning), Pendekatan Kontekstual atau Contextual Teaching and Learning (CTL) merupakan konsep belajar yang membantu guru mengaitkan antara materi yang diajarkan dengan situasi dunia nyata siswa dan mendorong siswa membuat hubungan antara pengetahuan yang dimilikinya dengan penerapannya dalam kehidupan mereka sebagai anggota keluarga dan masyarakat. Dalam konteks ini siswa perlu mengerti apa makna belajar, manfaatnya, dalam status apa mereka dan bagaimana mencapainya. Dengan ini siswa akan menyadari bahwa apa yang mereka pelajari berguna sebagai hidupnya nanti. Sehingga, akan membuat mereka memposisikan sebagai diri sendiri yang memerlukan suatu bekal yang bermanfaat untuk hidupnya nanti dan siswa akan berusaha untuk menggapainya.

Sebagaimana telah dikemukakan sebelumnya, secara umum permasalahan yang akan diteliti adalah "Bagaimana Pendekatan Kontekstual dapat Meningkatkan Sikap Ilmiah siswa pada Pembelajaran Gaya di Kelas V SD”. Masalah tersebut dijabarkan ke dalam rumusan yang lebih khusus, yaitu:

1. Bagaimana langkah-langkah pembelajaran gaya dengan menggunakan pendekatan kontekstual yang dapat meningkatkan sikap ilmiah siswa?

2. Bagaimana sikap ilmiah siswa selama mengikuti pembelajaran gaya dengan menggunakan pendekatan kontekstual?

3. Bagaimana pemahaman belajar siswa setelah mengikuti pembelajaran gaya dengan menggunakan pendekatan kontekstual yang dapat meningkatkan sikap ilmiah siswa?

Secara umum penelitian ini dilakukan dengan tujuan untuk memperbaiki kualitas pembelajaran agar siswa dapat mempelajari pengetahuan secara optimal sehingga berguna bagi kehidupannya di masa yang akan datang.

Secara khusus penelitian ini berupaya untuk:

a. mendeskripsikan langkah-langkah pembelajaran gaya dengan menggunakan pendekatan kontekstual. 
b. menumbuhkan sikap ilmiah siswa selama mengikuti pembelajaran gaya dengan menggunakan pendekatan kontekstual.

c. mengetahui peningkatan pemahaman siswa setelah mengikuti pembelajaran gaya dengan menggunakan pendekatan kontekstual.

\section{B. Tinjauan Pustaka}

Sikap ilmiah merupakan sikap yang harus ada pada diri seorang ilmuwan atau akademisi ketika menghadapi persoalan-persoalan ilmiah. Istilah sikap dalam bahasa Inggris disebut "Attitude" sedangkan istilah attitude sendiri berasal dari bahasa latin yakni “Aptus” yang berarti keadaan siap secara mental yang bersifat untuk melakukan kegiatan. Triandis (Bahrul, http://blogbahrul.wordpress.com/ 2007/11/28/sikap-ilmiah/) mendefenisikan sikap sebagai : “ An attitude ia an idea charged with emotion which predis poses a class of actions to aparcitular class of social situation".

Rumusan di atas diartikan bahwa sikap mengandung tiga komponen yaitu komponen kognitif, komponen afektif dan komponen tingkah laku. Sikap selalu berkenaan dengan suatu obyek dan sikap terhadap obyek ini disertai dengan perasaan positif atau negatif. Secara umum dapat disimpulkan bahwa sikap adalah suatu kesiapan yang senantiasa cenderung untuk berprilaku atau bereaksi dengan cara tertentu bilamana diperhadapkan dengan suatu masalah atau obyek.

Menurut Baharuddin (Bahrul, http://blogbahrul.wordpress.com/2007/11/ 28/sikap-ilmiah/) mengemukakan bahwa :"Sikap ilmiah pada dasarnya adalah sikap yang diperlihatkan oleh para Ilmuwan saat mereka melakukan kegiatan sebagai seorang ilmuwan. Dengan perkataan lain kecendrungan individu untuk bertindak atau berprilaku dalam memecahkan suatu masalah secara sistematis melalui langkah-langkah ilmiah. Menurut oleh National Curriculum Council (Bundu, P., 2006:39) sikap ilmiah yang sangat penting dimiliki pada semua tingkatan pendidikan sains adalah: hasrat ingin tahu, menghargai kenyataan (fakta dan data), ingin menerima ketidakpastian, refleksi kritis dan hati-hati, tekun, ulet, tabah, kreatif untukpenemuan baru, berpikir terbuka, sensitif terhadap lingkungan sekitar dan bekerjasama dengan orang lain

Sejalan dengan pertnyataan tersebut, Gage (Bundu, P., 2006:39) mengemukakan empat sikap pokok yang harus dikembangkan dalam sains yaitu “(a) curiosity, (b) inventiveness, (c) critical thinking, and (d) persistence. Keempat sikap ini sebenarnya tidak dapat dipisahkan antar satu dengan lainnya karena saling melengkapi. Adapun sikap ilmiah yang dijadikan sebagai fokus pada penelitian ini adalah empat sikap ilmiah menurut Gage yaitu keingintahuan (curiosity) siswa, yang mendorong akan penemuan sesuatu yang baru (inventiveness), yang berpikir 
kritis (critical thinking) dan meneguhkan pendirian (persistence) serta berani untuk berbeda pendapat.

Terdapat kecenderungan dewasa ini untuk kembali pada pemikiran bahwa anak akan belajar lebih baik jika lingkungan diciptakan alamiah. Belajar akan lebih bermakna jika 'anak mengalami' apa yang dipelajarinya, bukan 'mengetahui'-nya. Pembelajaran yang berorieritasi target penguasaan materi terbukti berhasil dalam kompetisi 'mengingat' jangka pendek, tetapi gagal dalam membekali anak memecahkan persoalan dalam kehidupan jangka panjang, dan itulah yang terjadi di kelas-kelas sekolah kita!

Tahap perkembangan berpikir siswa SD yang rata-rata berada pada usia 612 tahun, menunjukkan belum termasuk ke dalam tahapan formal tetapi masih berada dalam tahapan operasional kongkrit. Kemampuan mereka untuk memilah pengalaman belajar yang bersifat abstrak belum tumbuh. Oleh karena itu, pengalaman belajar yang akan mereka hayati haruslah dapat mereka lihat, dengar, cium, raba, atau rasakan. Agar pengalaman belajar dapat dihayati siswa secara efektif, diperlukan berbagai kondisi yang membuat belajar menjadi sesuatu yang menyenangkan bagi siswa. Selain itu guru hendaknya mengaitkan materi yang telah dimiliki siswa dengan kehidupan mereka sehari-hari, agar pembelajaran lebih bermakna.

Kemampuan kognitif siswa SD masih terikat dengan objek konkrit yang dapat ditangkap oleh panca inderanya. Maka dalam kegiatan belajar mengajar diperlukan media dan alat peraga yang dapat menjelaskan apa yang akan disampaikan oleh guru, sehingga lebih cepat dimengerti dan dipahami oleh siswa. Proses pembelajaran pada tahap operasional konkrit menurut Bruner (Dahar, RW., 1996:106) diungkapkan bahwa dalam proses belajar, sebaiknya siswa diberi kesempatan untuk memanipulasi benda-benda konkrit.

Pengertian kongkrit selain ditafsirkan sebagai pengunaan benda aslinya atau alat peraga yang dapat ditangkap oleh panca indera, tahap ini juga ditafsirkan sebagai kemampuan anak dalam operasional kongkrit, yaitu kemampuan yang dapat mengaitkan antar konsep yang disampaikan, dengan menampilkan pengalaman dan aktifitas yang diketahui atau pernah dialami siswa. Dengan demikian siswa dapat mengaitkan antara suatu konsep pembelajaran dengan tindakan atau perbuatan kehidupan nyata (Dahar, RW., 1996:105)

Dengan pengaitan pengalaman kehidupan nyata tersebut, diharapkan pembelajaran ini lebih bermakna dan mudah dipahami oleh siswa, baik secara konsep maupun aplikasinya dalam kehidupan sehari-hari. Sedangkan Hull \& Souders (ATEEC 2000:1) mengemukakan pula, bahwa dalam pembelajaran kontekstual, siswa menemukan hubungan yang bermakna antar ide-ide abstrak dengan aplikasi dalam konteks kehidupan nyata. Blanchard (2001:1) 
mengemukakan lebih lanjut dengan memberikan berbagai masalah dalam kehidupan sehari-hari yang belum ada penyelesaiannya, sebagai stimulus untuk belajar dengan mengaitkan dan mengorganisasikan informasi, siswa dapat mengaplikasikannya dalam kehidupan yang akan datang.

Dalam konteks itu siswa perlu mengerti apa makna belajar, apa manfaatnya, dalam status apa mereka, dan bagaimana mencapainya. Mereka sadar bahwa yang mereka pelajari berguna bagi hidupnya nanti. Mereka mempelajari apa yang bermanfaat bagi dirinya dan berupaya menggapainya. Dalam upaya itu, mereka memerlukan guru sebagai pengarah dan pembimbing. Dengan konsep itu diharapkan hasil belajar akan lebih bermakna bagi siswa. Proses pembelajaran berlangsung alamiah dalam bentuk kegiatan siswa bekerja dan mengalami, bukan transfer pengetahuan dari guru ke siswa. Ini mengandung arti guru lebih mementingkan strategi pembelajaran dari pada hasil belajar siswa. Pengetahuan juga bukan seperangkat fakta dan konsep yang siap diterima, tetapi sesuatu yang harus dikonstruksi sendiri oleh siswa (Depdiknas, 2002 : 2).

Menurut US Departement of Education (Doantara yasa, http://ipotes. wordpress.com/2008/05/13/pendekatan-kontekstual-atau-contextual-teaching-andlearning-ctl/) Pendekatan kontekstual (Contextual Teaching and Learning (CTL)) merupakan konsep belajar yang membantu guru mengaitkan antara materi yang diajarkannya dengan situasi dunia nyata siswa dan mendorong siswa membuat hubungan antara pengetahuan yang dimilikinya dengan penerapannya dalam kehidupan mereka sebagai anggota keluarga dan masyarakat. Dengan konsep itu, hasil pembelajaran dihadapkan lebih bermakna bagi siswa. Proses pembelajaran berlangsung alamiah dalam bentuk kegiatan siswa bekerja dan mengalami, bukan transfer pengetahuan dari guru ke siswa, melainkan bahwa strategi pembelajaran lebih dipentingkan daripada hasil.

Menurut Blanchard (Doantara yasa, http://ipotes.wordpress.com/2008/05/ 13/pendekatan-kontekstual-atau-contextual-teaching-and-learning-ctl/), ciri-ciri kontekstual: (1) Menekankan pada pentingnya pemecahan masalah (2) Kegiatan belajar dilakukan dalam berbagai konteks (3) Kegiatan belajar dipantau dan diarahkan agar siswa dapat belajar mandiri. (4) Mendorong siswa untuk belajar dengan temannya dalam kelompok atau secara mandiri. (5) Pelajaran menekankan pada konteks kehidupan siswa yang berbeda-beda. (6) Menggunakan penilaian otentik.

Senada dengan pernyataan tersebut, Depdiknas (2002:10-20) mengemukakan bahwa pembelajaran konstektual memiliki tujuh komponen utama yaitu konstruktivisme (constructivisme), menemukan (inquiri), bertanya (questioning), masyarakat belajar (learning community), pemodelan (modeling), refleksi (reflection) dan penilaian yang sebenarnya (authentic assesment). Pada 
pembelajaran kontekstual terjadi keterkaitan antara pengalaman siswa sebelumnya dengan topik yang akan diajarkan. Dimensi keterkaitan antar konsep dalam belajar disampaikan Ausubel (Dahar, 1996:110), bahwa belajar dapat diklafikasikan dalam dua dimensi. Pertama, berhubungan dengan cara informasi atau materi pelajaran pada siswa, melalui penerimaan atau penemuan. Dimensi kedua menyangkut cara bagaimana siswa dapat mengaitkan informasi itu pada struktur kognitif yang telah ada (telah dimiliki dan diingat). Pada pembelajaran kontekstual siswa harus menghubungkan apa yang telah dimiliki dalam struktur yang berupa konsep IPA dengan permasalahan yang ia hadapi.

Sebagai implementasi dari uraian-uraian di atas, maka akan dilakukan tindakan yang dipersiapkan untuk menyelesaikan masalah dalam melaksanakan proses belajar-mengajar di kelas dengan lebih berorientasi kepada pemerolehan konsep gaya oleh siswa, dan penggunaan LKS. Untuk menunjang penerapan kontekstual dalam pembelajaran gaya, maka digunakan metoda ceramah, demonstrasi, tanya-jawab dan kerja kelompok. Selain itu, ditunjang pula oleh pemberdayaan alat-alat peraga (modeling) untuk membantu guru dalam menyampaikan konsep-konsep gaya.

Dalam penerapan pendekatan kontekstual, tugas guru adalah membantu siswa mencapai tujuannya. Maksudnya, guru lebih banyak berurusan dengan strategi daripada memberi informasi. Tugas guru mengelola kelas sebagai sebuah tim yang bekerja bersama untuk menemukan sesuatu yang baru bagi siswa. Sedangkan pengetahuan dan keterampilan siswa akan tumbuh dari 'menemukan sendiri', bukan dari 'apa kata guru'. Maksudnya, guru lebih berurusan dengan strategi daripada memberi informasi. Guru hanya mengelola kelas sebagai sebuah tim yang bekerja sama untuk menemukan suatu yang baru bagi siswa. Proses belajar mengajar lebih diwarnai Student centered daripada teacher centered.

\section{Metodologi Penelitian}

Model penelitian tindakan kelas yang digunakan dalam penelitian ini adalah model siklus secara berulang dan berkelanjutan (spiral) yang berarti semakin lama diharapkan semakin meningkatkan perubahan/ pencapaian hasilnya (Elliot, J, 2003:21). Model ini terdiri dari empat komponen, yaitu: (1) perencanaan (planning), (2) pelaksanaan tindakan (action), (3) observasi (observation), dan (4) refleksi (reflection) dalam setiap siklus, dengan berpatokan pada refleksi awal.

Alokasi penelitian tindakan kelas ini dilaksanakan di SDN Sindanglaya 4 Kecamatan Mandalajati Kota Bandung. Subjek penelitian adalah siswa kelas V SD sebanyak 32 orang yang terdiri dari 17 orang siswa laki-laki dan 15 orang siswa perempuan. Sedangkan yang menjadi fokus dalam penelitian ini adalah sikap ilmiah siswa dan prestasi belajar siswa dalam proses pembelajaran gaya. 
Instrumen yang dikembangkan untuk mengetahui data tentang pelaksanaan dari setiap rencana tindakan adalah berupa pedoman observasi, lembar wawancara, catatan lapangan, lembar kerja siswa (LKS), soal evaluasi, dan kamera. Data yang diperoleh akan dianalisis pada setiap kegiatan sebagai pengujian terhadap hipotesis tindakan yang telah dirumuskan. Analisis data tersebut dilakukan dengan cara membandingkan transkip setiap instrumen kegiatan atau hasil kerja siswa. Pengolahan data dan analisis tersebut dilakukan secara terus menerus dari awal sampai akhir pelaksanaan tindakan pembelajaran. Data yang diperoleh dari penelitian dianalisis dengan menggunakan analisis data kualitatif dan analisis data kuantitatif. Analisis kualitatif digunakan untuk menganalisis data yang menunjukkan dinamika proses yang terjadi selama tindakan pembelajaran dan dideskripsikan kebermaknaan dari hasil penelitian. Sedangkan analisis data kuantitatif digunakan untuk mengetahui tingkat kemajuan siswa dalam pembelajaran.

\section{Hasil Penelitian dan Pembahasan}

Berdasarkan analisis terhadap sejumlah data yang diperoleh selama penelitian berlangsung, baik melalui observasi yang dilakukan oleh observer atau pengamatan dan pengalaman peneliti sendiri, serta dari sejumlah hasil tes akhir, menunnjukkan bahwa penerapan pendekatan kontekstual pada pembelajaran gaya dapat disimpulkan berhasil. Argument tersebut didasarkan pada sejumlah fakta yang diperoleh yakni:

Pada saat guru memberikan motivasi pembelajaran, tindakan pertama semua siswa diam dan tidak berani mengemukakan jawaban. Kemudian secara bertahap pada setiap tindakan tumbuh keberanian dan terjadi peningkatan kemampuan siswa dalam mengemukakan pertanyaan dan pendapat. Dalam hal ini, guru bersikap sabar, ramah dan terbuka tersebut, sehingga mampu menciptakan iklim belajar mengajar yang tepat melalui pengelolaan kelas yang baik, yang memungkinkan siswa merasa aman untuk belajar, seperti belajar sambil bermain dan bekerja (Usman, 1995:19). Pernyataan tersebut diperkuat oleh Winataputra (2001:3.4) yang mengemukakan bahwa proses pembelajaran akan berhasil apabila guru dapat mengkondisikan kegiatan belajar secara efektif

Dalam kegiatan pembentukkan kelompok pada tindakan 1 siklus I, terdapat dua siswa yang tidak bersemangat ketika bergabung dengan kelompoknya karena kecewa pembagian anggota kelompok dan terpisah dari teman sebangkunya. Berkaitan dengan peristiwa tersebut, maka dalam hal pembagian kelompok guru harus memperhatikan karakteristik siswa. Hal tersebut sesuai dengan pendapat Winataputra (2001:3.24) yang mengemukakan bahwa karakteristik siswa perlu diperhatikan dalam pembentukan kelompok terutama menyangkut kepandaian, 
jenis kelamin, kelancaran berbicara, serta kekuatan (kondisi) fisik siswa. Tetapi pada tindakan-tindakan selanjutnya siswa tersebut merasa senang dengan suasana belajar kelompok. Kondisi tersebut menunjukkan bahwa pada penelitian ini telah mampu mengkondisikan siswa dalam masyarakat belajar.

Dalam kegiatan kelompok, awalnya siswa terlihat bingung dengan aktivitas apa yang harus dilakukannya. Secara bertahap, pada tindakan tindakan berikutnya siswa mampu melakukan aktivitas percobaan tanpa bimbingan dari guru. Winataputra (2001:8.56) berpendapat bahwa dalam kegiatan berkelompok siswa mendapat kesempatan meningkatkan keterlibatannya dalam kegiatan pembelajaran. Hal ini menunjukkan bahwa siswa mampu mengkonstruksi pengetahuannya sendiri.

Selain itu, pada tindakan 1 siklus I setiap kelompok belum mampu menuliskan hasil percobaannya ke dalam LKS. Bahkan ada kelompok yang mencoba meniru apa yang dilakukan kelompok lainnya. Hal ini terjadi dikarenakan pada pembelajaran-pembelajaran sebelumnya siswa terbiasa menerima pembelajaran sebagai proses alih informasi dari guru, dari pada proses pencarian dan penggunaan informasi yang dimiliki siswa untuk memecahkan masalah (A. Tabrani Rusyan, dkk, 2000:7). Setelah dibimbing guru, siswa mulai mampu mengekspresikan sendiri petunjuk dalam LKS dan menuliskan hasil kegiatannya dalam LKS. Dengan demikian, siswa telah mampu menemukan pengetahuannya sendiri dalam pembelajaran tanpa harus diberitahu langsung oleh guru.

Pada tindakan 1 siklus I, suasana kelas menjadi gaduh karena siswa saling menuduh untuk membacakan hasil diskusi di depan kelas. Dalam hal tersebut, masih belum terdapat siswa yang berani untuk menanggapi hasil diskusi yang dibacakan tersebut. Tetapi pada kegiatan akhir siklus III terdapat satu orang siswa yang menanggapi presentasi kelompok lain yang jawabannya berbeda dengan jawaban kelompoknya. Kegiatan tersebut menunjukkan adanya hubungan timbal balik, tidak bersifat sepihak, dan tidak memandang guru sebagai satu-satunya subyek (Suprayekti, 2003:6). Dengan demikian dalam pembelajaran tersebut sudah terdapat interaksi (hubungan sosial siswa-siswa dengan guru) yang dimana didalamnya terdapat satu pertalian antar individu sehingga individu yang bersangkutan saling mempengaruhi satu sama lainnya (JP. Chaplin, 1999:254).

Dalam kegiatan diskusi kelompok tindakan 1, terdapat 2 kelompok yang mencoba meniru kegiatan kelompok lain karena tidak mengerti dengan langkahlangkah kegiatan yang terdapat pada LKS. Selanjutnya pada tindakan 2 setiap kelompok mampu melakukan kegiatan penemuannya sendiri tanpa meniru aktivitas kelompok lainnya. Kemudian, pada kegiatan membacakan hasil diskusinya didepan kelas, baik tindakan 1, dan 2 tidak diwakili oleh siswa yang sama pada tindakan setiap tindakannya, tetapi tidak menimbulkan kegaduhan. Hal 
ini dikarenakan siswa sudah terbiasa dengan kegiatan pembelajaran yang disajikan guru, sehingga setiap kelompok sudah mempersiapkan anggotanya untuk mewakili dalam membacakan hasil diskusi.

Peningkatan sikap yang dialami oleh siswa menunjukkan tercapainya sikap ilmiah dalam pembelajaran IPA. Dalam hal ini siswa menunjukkan rasa ingin tahu, penemuan, berpikir kritis dan tekun. Peningkatan sikap ilmiah pada pembelajaran ini sesuai pendapat Gega (Bundu, P., 2006:39) yang mengemukakan bahwa terdapat empat sikap pokok yang harus dikembangkan dalam sains yaitu keingintahuan (curiosity) siswa, yang mendorong akan penemuan sesuatu yang baru (inventiveness), yang berpikir kritis (critical thinking) dan meneguhkan pendirian (persistence) serta berani untuk berbeda pendapat.

Selanjutnya, pada kegiatan evaluasi, baik tindakan 1 maupun 2 suasana terlihat tenang karena semua siswa bekerja secara individual. Dari analisis nilai hasil evaluasi, diperoleh kesimpulan bahwa nilai rata-rata siswa pada tindakan 1 dan 2 mengalami peningkatan yang cukup signifikan. Dari hasil pengamatan terhadap sikap ilmiah siswa diperoleh data bahwa kemampuan mengungkapkan ide/gagasan rata-rata mencapai 28,813 dan kerjasama dalam kelompok mencapai rata-rata 26,56. Menurut Baharuddin (Bahrul, http://blogbahrul.wordpress.com/ 2007/11/ 28/sikap-ilmiah/) mengemukakan bahwa :"Sikap ilmiah pada dasarnya adalah sikap yang diperlihatkan oleh para Ilmuwan saat mereka melakukan kegiatan sebagai seorang ilmuwan. Dengan perkataan lain kecendrungan individu untuk bertindak atau berprilaku dalam memecahkan suatu masalah secara sistematis melalui langkah-langkah ilmiah. Berikut ini disajikan prosentase untuk aktivitas dan pengamatan siswa dalam setiap siklus:

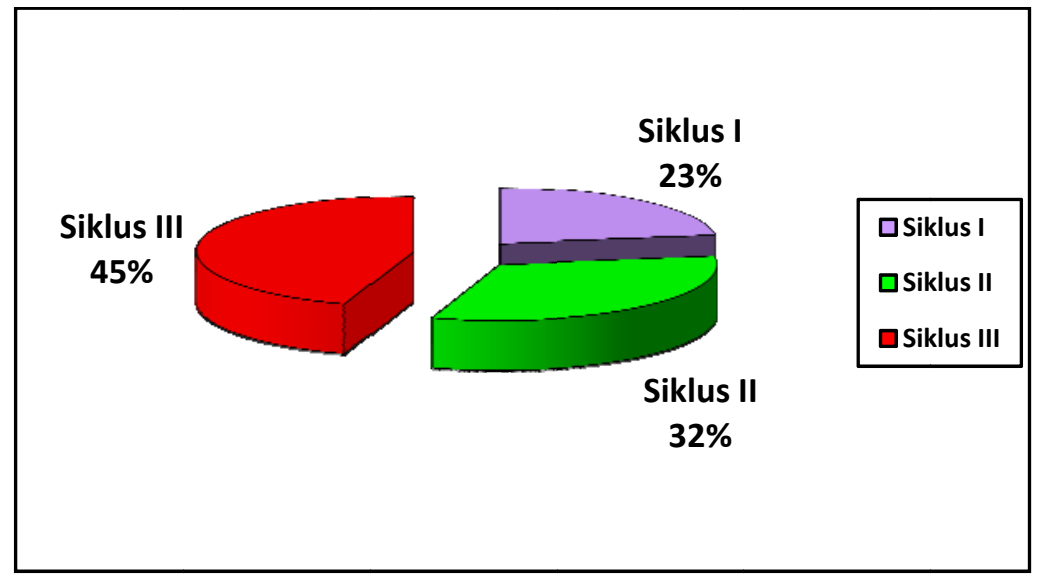

Gambar 1

Diagram Prosentase Rata-rata Kemampuan Mengungkapkan Ide Pada Setiap Siklus 


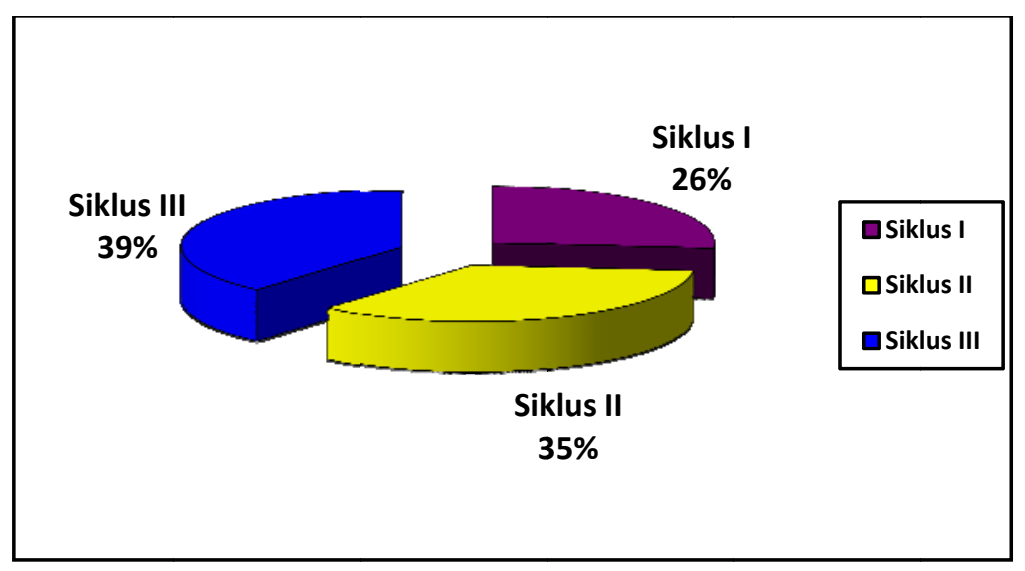

Gambar 2

Diagram Prosentase Rata-rata Kerjasama Siswa Pada Setiap Siklus

Pada kegiatan akhir, di mana siswa mengerjakan soal-soal evaluasi secara individual, suasana terlihat tertib karena setiap siswa mengerjakan soal-soal evaluasi secara individual. Dari hasil pemeriksaan terhadap jawaban siswa, diperoleh data nilai rata-rata siklus I sebesar 77,97; pada siklus II mencapai 80,94; dan pada siklus III mencapai rata-rata 85,63. Berikut ini disajikan grafik perolehan nilai rata-rata hasil tes akhir individu pada setiap tindakan siklus I sampai III:

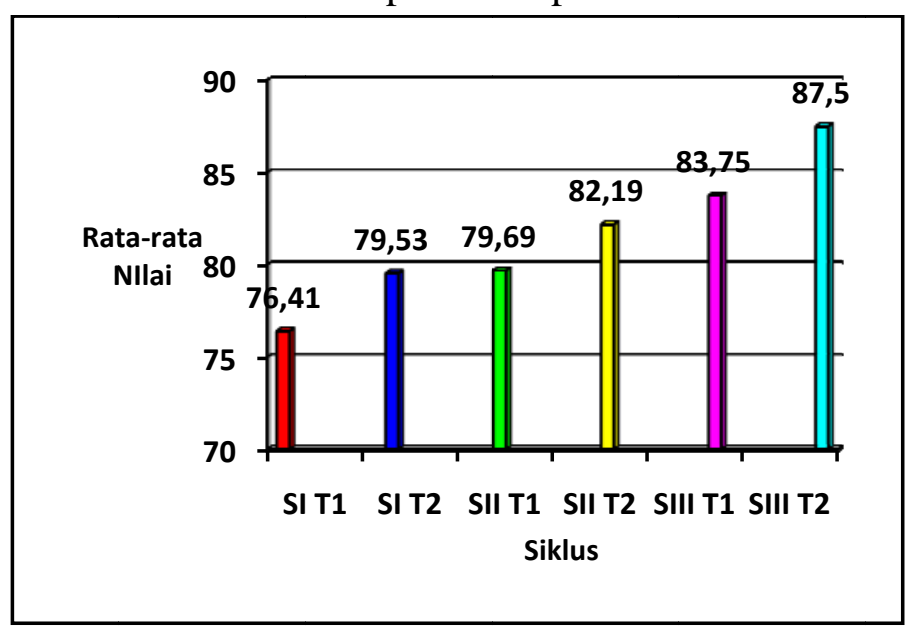

Gambar 3

Grafik Rekapitulasi Perolehan Nilai setiap tindakan Siklus I, II dan III

Dengan demikain, melalui penerapan model kontekstual dan metode diskusi, selain pemahaman siswa meningkat, siswa juga menjadi aktif, lebih semangat dalam mengikuti pelajaran, mempunyai kemauan untuk mengemukakan pertanyaan dan menjawab pertanyaan, sehingga terjalin hubungan timbal balik yang harmonis antara siswa dengan guru, siswa dengan model dan antarsiswa (Nurjamin, 2004). Selain itu juga dibuktikan dengan adanya peningkatan sikap 
ilmiah siswa pada aktivitas dan pengamatan kelompok. Serta didukung oleh perolehan nilai rata-rata individu yang semakin meningkat.

\section{E. Simpulan dan Saran}

1. Pembelajaran materi gaya di kelas V Sekolah Dasar sangat tepat apabila diajarkan dengan menggunakan pendekatan kontekstual yang dilaksanakan dengan menempuh 7 langkah kontekstual, yaitu. a). Kontruktivisme, yaitu proses membangun atau menyususn pengetahuan baru dalam struktur kognitif siswa berdasarkan pengalaman.; b) Inkuiri, yaitu pembelajaran yang didasarkan pada pencarian dan penemuan melalui proses berpikir yang sistematis; c) Bertanya untuk mengembangkan sifat ingin tahu siswa; d) Masyarakat belajar dapat dilakukan dengan menerapkan pembelajaran melalui kelompok belajar ; e) Pemodelan dengan menjadikan pengalaman perwakilan siswa sebagai contoh pembelajaran; f) Refleksi yaitu proses pengendapan pengalaman yang telah dipelajari dan g) melakukan penilaian sebenarnya dengan berbagai cara.

2. Penggunaan pendekatan kontekstual pada materi gaya juga dapat meningkatkan sikap ilmiah siswa pada proses pembelajaran dalam rangka pemerolehan pengetahuan. Hal tersebut ditunjukkan dengan siswa menjadi lebih berani dan aktif bertanya, aktif mengemukakan pendapat dan siswa aktif bekerjasama dalam kegiatan kelompok.

3. Pemahaman belajar siswa dalam materi gaya mengalami peningkatan setelah dilaksanakannya pembelajaran dengan menggunakan pendekatan kontekstual. Hal ini ditunjukkan dengan adanya peningkatan nilai hasil belajar siswa baik secara kelompok maupun individual. Hasil belajar siswa dalam kegiatan kelompok pada siklus I mencapai rata-rata 87,92; pada siklus II mencapai 91,08 dan pada siklus III mencapai 92,50. Sedangkan nilai rata-rata hasil belajar siswa yang diperlakukan secara individual pada siklus I mencapai 77,97; pada siklus II mencapai 80,94; dan pada siklus III mencapai 85,63.

4. Dalam pembelajaran Ilmu Pengetahuan Alam (IPA) pokok bahasan gaya maupun pokok bahasan lainnya, selain hasil hendaknya pembelajaran lebih menekankan pada proses bagaimana mengembangkan sikap ilmiah siswa. guru harus berperan sebagai fasititator yang bertugas menumbuhkan keingintahuan siswa, mendorong akan penemuan sesuatu yang baru, berpikir kritis dan meneguhkan pendirian siswa serta memberikan kesempatan kepada siswa untuk berani berbeda pendapat.

5. Untuk meningkatkan pemahaman siswa terhadap materi yang dibelajarkan, guru harus lebih kreatif dalam menggunakan metoda pembelajaran yang akan digunakannya, menggunakan bahasa yang sesuai dengan tingkat pemahaman siswa dan berdasarkan konteks yang lebih dekat dengan kehidupan siswa 
dalam membuat soal serta mengajarkan materi secara sistematis dengan memperhatikan kemampuan awal siswa.

\section{DAFTAR PUSTAKA}

ATEEC, (2000). Teaching for Contextual Learning. [on line]. Tersedia di http://www.Ateec.org/curic.Ctl info.cfm. 8 Februari 2009

Bahrul (2007). Sikap Ilmiah. [On line]. Tersedia di http://blogbahrul.wordpress.com/ 2007/11/28/sikap-ilmiah/. 8 Februari 2010.

Blanchard (2001). Contextual Teaching and Learning Primari Learning Theories. [on line]. Tersedia di http://www. Bested educational.service. Com//contextual/htm. 8 Februari 2010

Bundu, P., (2006). Penilaian Proses dan Sikap Ilmiah. Bandung: UPI Press

Chaplin (1999). Kamus Lengkap Psikologi (terjemahan Kartini Kartono). Jakarta: PT. Raja Grafindo Persada

Dahar, (1996). Teori-Teori Belajar. Jakarta. Erlangga.

Depdiknas, (2002). Pendekatan Kontekstual. Jakarta: Direktorat Pendidikan Dasar dan Menengah.

Doantara Yasa (2008). Pendekatan Kontekstual (Contxtual Teaching and Learning). [Online]. Tersedia : http://ipotes.wordpress.com/2008/05/13/ pendekatan-kontekstual-atau-contextual-teaching-and-learning-ctl/). $\quad 28$ Februari 2010.

Karli, H. dan Sri, YM. (2002). Implementasi Kurikulum Berbasis Kompetensi : Model-model Pembelajaran. Bandung:

Nurjamin (2004). Penerapan Model Kontekstual Dalam Pembelajaran Lapangan Kerja Untuk Siswa Kelas IV Sekolah Dasar. Skripsi. Universitas Pendidikan Indonesia

Rusyan, Tabrani, dkk (2000). Upaya Meningkatkan Budaya Kinerja Guru Sekolah Dasar. Jakarta: Nusantara Lestari Ceria Pratama.

Suprayekti (2003). Interaksi Belajar Mengajar. Jakarta: Depdiknas, Dirjen Dikdasmen

Usman, U., (1995). Menjadi Guru Profesional. Bandung: PT. Remaja Rosda Karya.

Winataputra (2001). Strategi Belajar Mengajar. Jakarta: Universitas Terbuka.

\section{Biodata Singkat Penulis}

Iin Hindasah adalah guru pada Sekolah Dasar Negeri Sindanglaya 4 Kecamatan Mandalajati, Kota Bandung. Penulis menyelesaikan pendidikan jenjang sarjana (S-1) Pendidikan Guru Sekolah Dasar Universitas Pendidikan Indonesia Kampus Cibiru, Konsentrasi Ilmu Pengetahuan Alam (IPA). 